\title{
INFLUENCE OF THE EXPERIMENTAL CONDITIONS ON THE REMOVAL OF DYES FROM AQUEOUS SOLUTIONS USING ULTRAFILTRATION
}

\author{
E. N. El - Qada' ${ }^{1}$ and N. M. Haimour ${ }^{2}$ \\ ${ }^{1}$ Chemical Engineering Technology Department, Yanbu Industrial College, \\ P.O. Box 30436, SA-21477 Yanbu Al Sinaiyahh, Kingdom of Saudi Arabia, \\ Tel:00966566964299, Email: e_anadele@yahoo.com \\ ${ }^{2}$ College of Engineering, King Faisal University, \\ Email:nhaimour@kfu.edu.sa
}

\begin{abstract}
The main aim of this paper is to investigate the ability of hollow fiber ultrafiltration membrane of MWCO of $5 \mathrm{KD}$ made of polysulfone to remove reactive dyes from wastewater. Two reactive dyes, violet 5R and C.I red 222.1, were studied under different experimental conditions of flow rate, temperature, concentration, $\mathrm{pH}$, and transmembrane pressure to determine the best conditions under which the highest percentage of dye removal can be achieved. Binary systems of the two dyes prepared in different ratios to study the ability of membrane to treat solutions containing dye mixtures. It was showed that $91 \%$ of violet dye removal and $88 \%$ of red dye removal were achieved when both dyes were treated individually. Flow rate and $\mathrm{pH}$ proved to have great effects on membrane performance in the case of violet dye whereas solution $\mathrm{pH}$ showed the greatest effect for red dye removal. For the binary systems, it was found that interactions between dyes are not significant. Solutions with properties similar to that of the effluents from textile industry were prepared and $6 \%$ of violet dye removal as well as $20 \%-80 \%$ of red dye removal were achieved. Resistance In Series model was applied to find the flux theoretically which showed agreement with experimental values with a variable error ranging from $2-21 \%$.
\end{abstract}

KEYWORDS: Ultrafiltration, Hollow Fiber Membrane, Reactive Dyes, Wastewater Treatment, Rejection Factor.

\section{INTRODUCTION}

Great attention has been paid to the quality of effluents discharge from many industries. "Colored wastewater is produced from textile industry, dye manufacturing, sugar and paper industries, etc". Since these industries consume large amounts of water, they are considered a major source of pollution $[1,2]$. This is paralleled with increased demand currently being placed on water supply and waste disposal, and thus have necessitated broader concepts in the application of wastewater treatment.

Received, April 7, 2010; accepted June 26, 2010 
This led to innovate many methods for wastewater treatment. The existing treatment techniques, which are applied to decolorize wastewater, are classified into two main categories. In the first category, color species are destroyed or modified, such as physical oxidation and biological degradation. The other category, the colored species are removed from wastewater, such as: adsorption, membrane filtration [3,4]. Among these, membrane filtration is of concern.

In the last decade, membrane filtration technology has gained industry acceptance as a viable, economical and efficient water treatment option $[4,5]$. In addition to that, it can be used in many applications such as: concentration of suspension of fine particles or colloidal material or fractionation of solutions of macromolecules [6].

Cross-flow filtration can be divided into many groups: reverse osmosis, ultrafiltration, nanofiltration, microfiltration, etc.

Ultrafiltration is a pressure-driven pro-cess used to segregate substances according to their molecular weight and size. It is usually used to separate molecules having molecular weights of greater than 500 and up to 1000000 or more such as proteins, polymers, clays, latex particles and microorganisms [7]. Many advantages can be related to colour removal using ultrafiltration and can be summarized as follow:

It involves no change in phase of the solvent during dewatering process and this results in considerable saving in energy, low osmotic pressure, which result in low operation pressure, no condensers are needed, so thermal pollution and overloading of sewage treatment system are avoided, much higher recoveries of the retained material and a big advantage is the "back-flushing" capability, which vastly improves its cleanibility.
A major drawbacks arising on the use of ultrafiltration are the fouling of the membrane and the concentration polarization phenomena.

One of the common ultrafiltration membranes designs is the hollow fiber configuration in which the membrane is formed on the inside of tiny polymer cylinder fabricated into a tube-and-shell arrangement [8]. This configuration is character-ized to operate in laminar flow region with very high shear rate and highest surface area-to-volume ratio [9].

The ability of capillary polysulfone membranes in decolourization of both synthetic and actual dye solutions by using ultrafiltration was studied by Winnicki [10]. 92-99 \% retention coefficient for organic dyes of molecular weight higher than 780 was obtained. For actual textile effluents, the removal efficiency of colour was 70-98 \%.

Majewska et al. [11] described the ability of polysulfone membranes to separate direct meta black dye from aqueous solution by means of ultrafiltration. It was found that polysulfone mem-brane formed on a glass support can be used to separate direct dye of molecular weight equal to or higher than 700 . $95-100 \%$ of dye separation was achieved.

This work investigates the feasibility of using a polysulfone hollow fiber membrane to remove violet $5 \mathrm{R}$ and C.I red 222.1 reactive dyes. A further aim is to study the effect of flow rate, initial dye concentration, $\mathrm{pH}$, pressure difference and tempe-rature on permeate flux and dye rejection.

\section{MATHEMATICAL MODEL}

Few models are available in literature that attempt to describe the mechanism of transport through membranes. The Resistance In Series model relates the 
permeate flux from the membrane surface to the transmembrane pressure as:

$$
J_{v}=\frac{\Delta P_{T}}{R_{m}+R_{f}+R_{P}}
$$

where $\mathrm{R}_{\mathrm{m}}$ : intrinsic membrane resistance (Pa.hr $/ \mathrm{m}) ; \mathrm{R}_{\mathrm{f}}$ : resistance due to fouling phenomenon $(\mathrm{Pa} . \mathrm{hr} / \mathrm{m}) ; \mathrm{R}_{\mathrm{P}}$ : resistance due to concentration polarization phenomenon $(\mathrm{Pa} . \mathrm{hr} / \mathrm{m}) . \Delta \mathrm{P}_{\mathrm{T}}$ is given by:

$\Delta P_{T}=0.5 *\left(P_{i}+P_{o}\right)-P_{P}$

where $\Delta \mathrm{P}_{\mathrm{T}}$ : the transmembrane pressure (bar); $\mathrm{P}_{\mathrm{i}}$ : inlet membrane pressure (bar); $\mathrm{P}_{\mathrm{o}}$ : outlet membrane pressure (bar); $\mathrm{P}_{\mathrm{p}}$ : permeate backpressure (bar).

Since concentration polarization forms a compressible layer [8], $R_{P}$ is function of pressure, and it can be related to pressure in the following manner:

$$
R_{P}=\Phi * \Delta P_{T}
$$

where $\Phi$ : is a proportional constant.

Equation (1) can be rewritten as:

$$
J_{v}=\frac{\Delta P_{T}}{R_{m}+R_{f}+\Phi \Delta P_{T}}
$$

The values of $R_{m}, R_{f}$ and $\Phi$ can be determined experimentally.

In the case of pure water, gel polarization and fouling phenomena do not exist, so equation (1) can be written as:

$$
J_{w}=\frac{\Delta P_{T}}{R_{m}}
$$

where $J_{\mathrm{w}}$ : Pure water flux $\left(\mathrm{cm}^{3} / \mathrm{cm}^{2} . s\right)$.

\section{EXPERIMENTAL}

\subsection{Materials}

Two reactive dyes, which pose significant problems for removal by conventional technologies, were chosen as principal pollutants; violet 5R (Molecular mass $=1064)$ and C.I red 222.1 (Molecular mass = 995.23), supplied by Ortho Chemicals Australia, Pty, Ltd., Australia. Fig. (1) depicts the chemical structure for Violet 5R and C. I red. Deionised water $(18.2 \mu \Omega)$ was used as a solvent in this work to prepare stock dye solutions.

\subsection{Procedure}

A schematic diagram of the apparatus used is shown in Fig. 2. The feed solution is pumped from the feed tank to the membrane module. A hollow fiber cartridge (UFP-5-E-4A model) from A/G Technology Corporation, Needham, MA, USA was used.

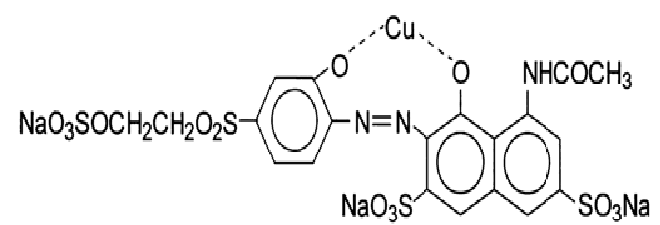

(a)

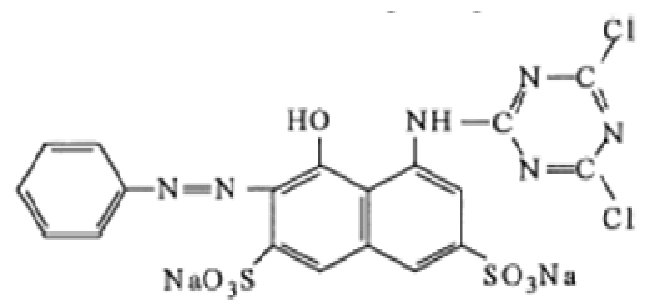

(b)

Fig.1. Chemical structure of (a) violet 5R, (b) C.I red.

The fibers are made of polysulfone. The nominal molecular weight cut-off (NMWCO) of the membrane is 5,000 and its effective surface area is $0.032 \mathrm{~m}^{2}$.

A constant temperature water bath was used to control the temperature of the feed. Permeate and reject flow rates were measured by collecting $50 \mathrm{ml}$ of each and determine the time required to collect them. A spectrophotometer was used to measure the absorbance of dye in permeate and concentrate streams. 
From the calibration curve of the dye, the concentrations of the dye in permeate and concentrate streams were determined. Runs using distilled water were used to determine the membrane resistance.

The parameters studied were temperature, transmembrane pressure, feed flow rate, $\mathrm{pH}$ and feed concentration. To investigate the effect of the operating time, runs were performed for 6 hours at $\mathrm{T}=30^{\circ} \mathrm{C}$, concentration $=50 \mathrm{ppm}$, flow rate $=35.3 \mathrm{~L} / \mathrm{hr}$ and $\Delta \mathrm{P}=1$ bar.

\subsection{MiXTURe OF DYES}

This was studied by ultafiltrating several solutions with different concentration ratios. First, one of the dyes was kept at constant concentration while the concentration of the second dye was changed and the reverse was carried out. 1:10, 3:10, 5:10, 7:10, 9:10 and $10: 10$ of the concentration ratios were used. Flux and concentration of the dyes in the permeate and in the concentrate streams were measured as in the case of single dye, but in this case the absorbance of the permeate and that of the concentrate was measured at the wavelengths 560 and $500 \mathrm{~nm}$.

\subsection{SyNTHETIC TEXTILE INDUSTRY EFFLUENT}

In this part of work, solutions of violet and reactive red dyes with properties similar to that of textile industry effluents were treated by ultrafiltration membrane to study the effect of the presence of materials other than dye on membrane performance.

\section{RESULTS AND DISCUSSION}

\subsection{Determination of Membrane Resistance}

Pure water flux through clean ultrafiltration membrane was determined at different flow rates. It was found that water permeability was constant throughout all the experiments. This means that the membrane resistance is constant. This resistance was calculated and found to be equal to $560(\mathrm{~Pa} \cdot \mathrm{hr} / \mathrm{m})$. Similar behavior of ultrafiltration membrane was reported in the works of Caric' et al. [12] and Nakeo and Kimura [13].

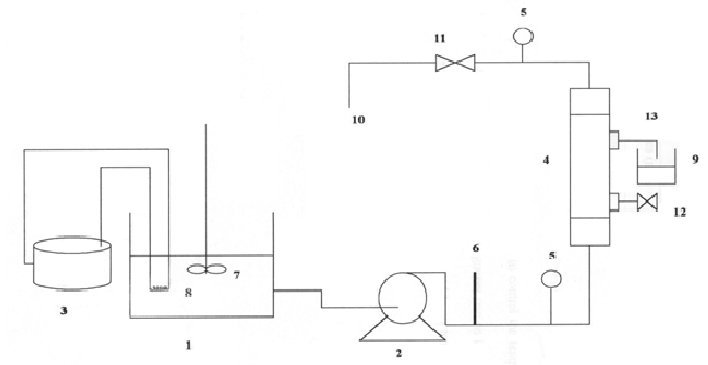

Fig.2. Schematic diagram of the apparatus setup.

1- Feed tank 2- Pump 3- Water bath 4- Hollow fiber membrane cartridge 5- Pressure gauge 6-Thermo-meter

7- Stirrer 8- Heating coil 9- Graduated flask 10-

Retentate line 11- Control valve 12- Hose clamp, closed 13- Permeate line.

\subsection{FLUX AND MEMbRANE RETENTIVITY MeAsurements}

Many factors affect the permeate flux and membrane retentivity. Some of these can be related to the membrane itself like type of membrane material, membrane properties, and membrane configuration. Other factors can be related to the solute such as size and shape of molecules, presence of the other solutes impurities, concentration of retained species and the formation of secondary dynamic membrane [9].

Membrane retentivity can be expressed in terms of rejection factor which depends on dye concentration in permeate and the feed streams [14].

$$
R=1-\frac{C_{P}}{C_{f}}
$$

Removal of dyes from wastewater using ultrafiltration membrane is controlled by many factors, which will be demonstrated below. 


\subsubsection{Effect of Flow Rate}

Direct relationship exists between the permeate flux through the membrane and the mass transfer coefficient. Flow rate has been seen to have great effect on the mass transfer coefficient or permeate flux. The magnitude of this effect depend on whether the flow is turbulent or laminar and the rheological properties of the fluid, i.e., whether it is Newtonian or non - Newtonian [9].

The relationship between the permeate flux through a membrane and the mass transfer coefficient is, generally, given for laminar flow by:

$\mathrm{NSh}=0.664 *(\mathrm{NRe} d \mathrm{dh} / \mathrm{L})^{0.5} \mathrm{NSc}{ }^{0.33}$

For turbulent flow, the best-known correlation is that of Dittus and Boelter [15]:

$\mathrm{NSh}=0.023(\mathrm{NRe})^{0.8}(\mathrm{NSc})^{0.33}$

According to equations (7) and (8), by increasing flow rate the mass transfer coefficient will increase and enhance the flux. The experimental results had shown an inverse relationship between flow rate and the flux. i.e. increasing flow rate decrease the permeate flux. This result agrees with the work of [16] in ultrafiltration of human albumin.

Another unexpected membrane behavior was noticed, that, if the experiments were carried out in the same day, the flux decreases with increasing flow rate. But if experiments were stopped then carried out the next day, at higher flow rate, it was found that the flux had value similar to that obtained before stopping, which is in contrast with the behavior mentioned above i.e. increasing flow rate will decrease permeate flux. This can be explained as follows; as the flow rate increases, the membrane faces certain degree of compression, which causes membrane deformation and reduces pore sizes and results in flux decline. The more the increase in the flow rate, the more the reduction in pore size. When flow is stopped, the membrane returns to its original shape and pore size. Fig. (3) shows the relationship between flux and flow rate of violet dye.

The rejection factor has increased from $13 \%$ to $82 \%$ for violet dye and from $20-52 \%$ for red dye by increasing flow rate from 8.5 to $35.3 \mathrm{l} / \mathrm{h}$ as shown in Fig. (4).

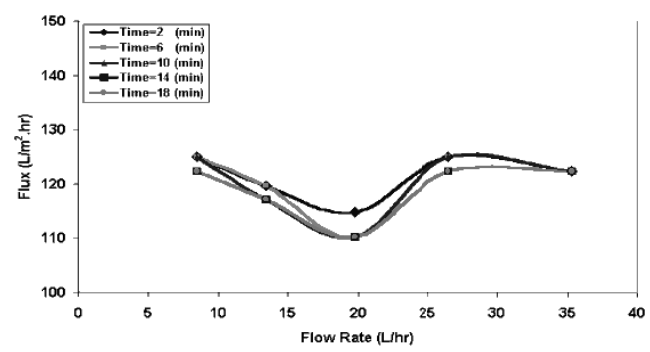

Fig.3. Effect of flow rate on permeate flux for violet dye. $\Delta \mathrm{P}=1$ bar, concentration $=50 \mathrm{ppm}, \mathrm{pH}=5$ and $\mathrm{T}=30^{\circ} \mathrm{C}$.

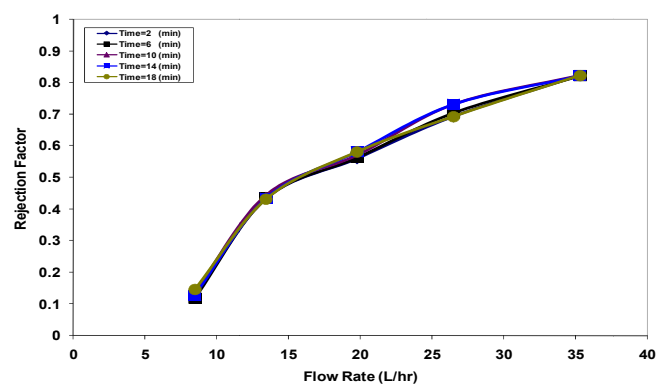

Fig.4. Effect of flow rate on rejection factor for violet dye. $\Delta \mathrm{P}=1$ bar, concentration $=50 \mathrm{ppm}, \mathrm{pH}=5$ and $\mathrm{T}=30^{\circ} \mathrm{C}$.

\subsubsection{Effect of Temperature}

From the experimental results, an increase of $41 \%$ of violet dye flux and $44 \%$ of red dye flux was observed as the temperature increased from $25^{\circ} \mathrm{C}$ to $50^{\circ} \mathrm{C}$. Fig. (5) shows the effect of temperature on permeate flux for red dye. The increase in flux is due to the decrease in the solution viscosity and the increase in dye solubility. Grieves et al. [17] reported the same effect of temperature in ultrafiltration of nonionic surfactant. 
Rejection factor is inversely proportional to solution temperature. Fig. (6) shows the effect of temperature on the rejection factor of the red dye. This can be explained due to the decrease in solution viscosity, which facilitates the passage of dye solute through membrane pores.

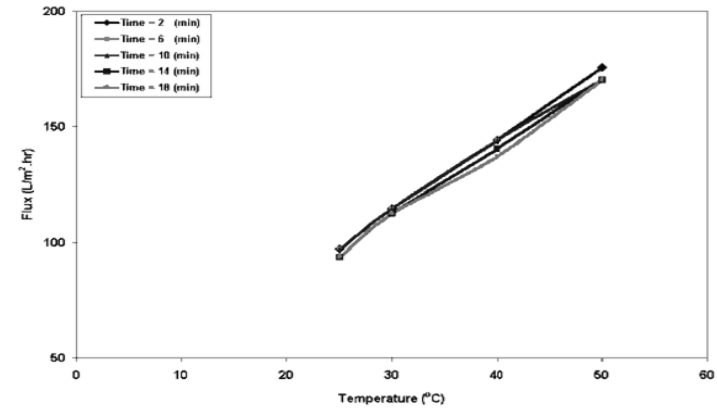

Fig. 5. Effect of temperature on permeate flux for red dye. $\Delta \mathrm{P}=1$ bar, concentration $=50 \mathrm{ppm}, \mathrm{pH}=5$ and flow rate $=35.3 \mathrm{~L} / \mathrm{hr}$.

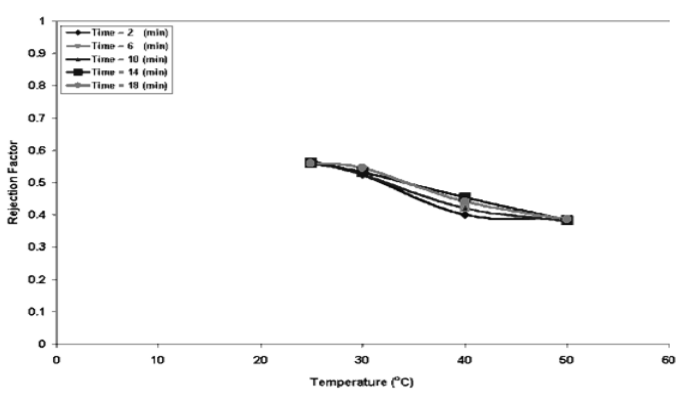

Fig.6. The effect of temperature on rejection factor of the red dye. $\Delta \mathrm{P}=1$ bar, concentration $=50 \mathrm{ppm}, \mathrm{pH}=5$ and flow rate $=35.3 \mathrm{~L} / \mathrm{hr}$.

\subsubsection{Effect of Feed Concentration}

Flux is highly dependent on feed solution and overall dye concentration. Increasing the feed concentration will decrease the permeate flux, since changes in feed concentration will affect the density and viscosity of the feed solution. Gel polarization model explains this behaviour and shows that flux decreases exponentially with increasing feed concentration.

As the concentration increased from 10-100 ppm, $12 \%$ and $18 \%$ reduction in permeate flux of violet and red dyes respectively was observed. This agrees with the result obtained by Ahmad and Puasa [14].

The authors studied the removal of reactive dyes, C.I. Reactive Black 5 (RB5) and C.I. Reactive Orange 16 (RO16) using micellarenhanced ultrafiltration (MEUF). The authors found that the permeate flux decreases with the increase in the feed concentration at fixed operating pressure of $300 \mathrm{kPa}$. The variation of permeate flux with dye concentration is shown in Fig. (7) for violet dye. Feed concentration does not have a significant effect on the rejection factor as shown in Fig. (8). The operating time may not be enough to form gel layer to affect the rejection factor.

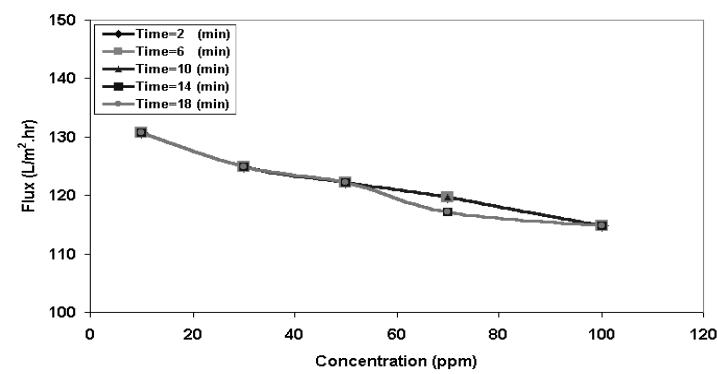

Fig.7. The effect of concentration on flux of the violet dye. $\Delta \mathrm{P}=1$ bar, $\mathrm{T}=30^{\circ} \mathrm{C}, \mathrm{pH}=5$ and flow rate $=35.3$ $\mathrm{L} / \mathrm{hr}$.

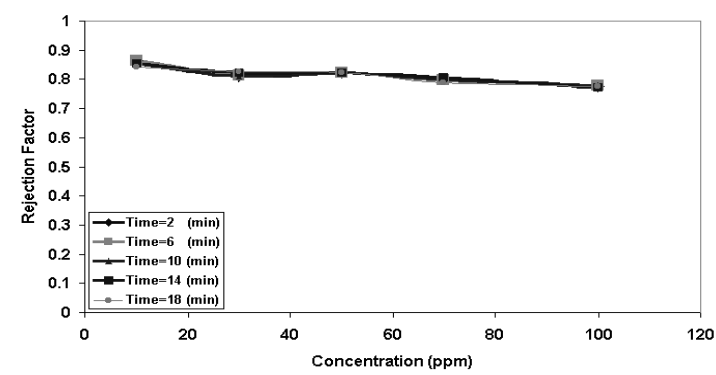

Fig. 8. The effect of concentration on rejection factor of the violet dye. $\Delta \mathrm{P}=1$ bar, $\mathrm{T}=30$ o $\mathrm{C}, \mathrm{pH}=5$ and flow rate $=35.3 \mathrm{~L} / \mathrm{hr}$.

\subsubsection{Effect of $\mathrm{pH}$}

$\mathrm{pH}$ may affect both the compatibility and the stability of the membrane. It also has an effect on the solubility of dyes. Increasing $\mathrm{pH}$ 
will decrease solubility of dye. $\mathrm{pH}$ range from 3 to 11 for the two dyes have been studied.

Fig. (9) shows the behavior of flux as a function of $\mathrm{pH}$ for the violet dye. The experimental results show that extremely acidic range $(\mathrm{pH}=3)$ was unsuitable for dyes removal, only $50-60 \%$ dye removal was achieved for the violet dye and 33-42\% for the red dye.

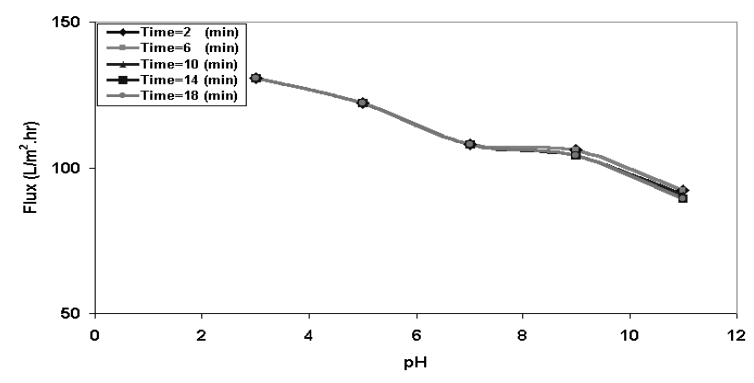

Fig.9. The effect of $\mathrm{pH}$ on the flux of the violet dye. $\Delta \mathrm{P}=1$ bar, $\mathrm{T}=30 \mathrm{o} \mathrm{C}$, concentration $=50 \mathrm{ppm}$ and flow rate $=35.3 \mathrm{~L} / \mathrm{hr}$.

From $\mathrm{pH}=5$ to $11, \mathrm{pH}$ had good dye removal with little variation in rejection factor values for violet dye and high variation in rejection values for reactive red dye as shown in Fig. (10).

\subsubsection{Effect of Transmembrane Pressure}

Permeate flux increases with increasing transmembrane pressure. The relationship between the flux and the transmembrane pressure can be expressed by the resistance in series model according to equation (1). Fig. (11) shows the behavior of permeate flux as a function of transmembrane pressure for red dye. This behavior was reported in the work of $[17,18,19,20]$.

According to the rejection factor values, it is clear that as transmembrane pressure increased from 0.8 bar to 1.0 bar, the membrane performance was improved. However, a further increase in transmembrane pressure caused a shift in dyes retention.

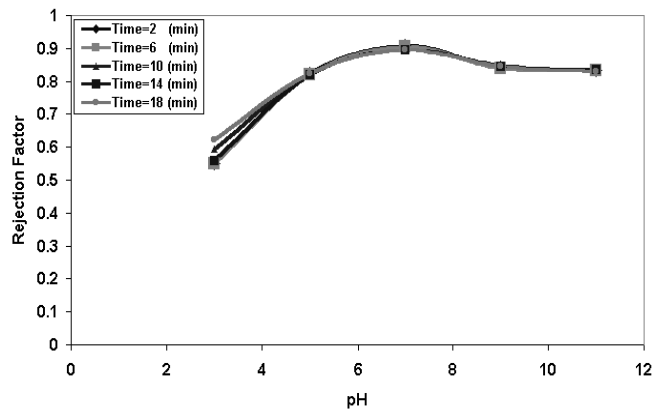

Fig. 10. The effect of $\mathrm{pH}$ on the rejection factor of violet dye. $\Delta \mathrm{P}=1$ bar, $\mathrm{T}=30 \mathrm{oC}$, concentration $=50$ $\mathrm{ppm}$ and flow rate $=35.3 \mathrm{~L} / \mathrm{hr}$.

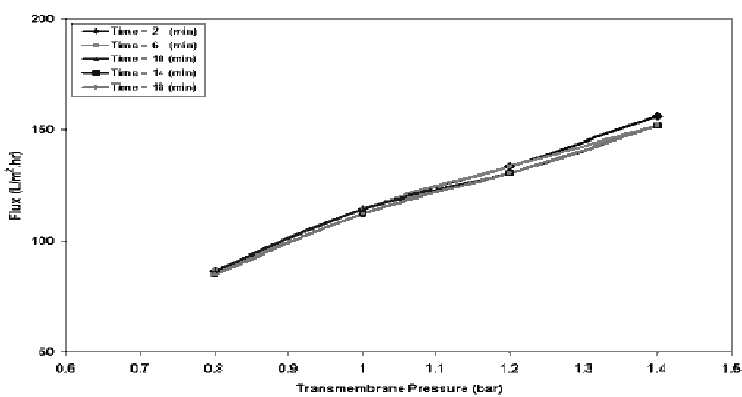

Fig.11. The effect of transmembrane pressure on the flux of red dye. $\mathrm{T}=30 \mathrm{o} \mathrm{C}$, concentration $=50 \mathrm{ppm}$ and flow rate $=35.3 \mathrm{~L} / \mathrm{hr}, \mathrm{pH}=5$.

In other word, increasing pressure from 1.0 bar to 1.4 bar caused a decrease in membrane retention. This is in agreement with Rudie et al., [21]. Rudie et al., [21] explained this behavior using the concept of critical flux.

Critical flux can be defined as the flux for which the shear induced by the flow through the pore is high enough to overcome the natural tendency of a solute molecule to maintain its spherical shape in solution. By increasing the pressure to 1.2 bar or to $1.4 \mathrm{bar}$, the flux reaches its critical value and shear will elongate and/or deform the molecule such that it will pass through the membrane pores. Fig. (12) shows this shift in membrane retention for the red dye. 


\subsection{EVAluation OF FLUX TheORETICALLY}

Resistance In Series model was used to evaluate the flux theoretically. The model relates flux to transmembrane pressure as in equation (4).

A plot of $1 / \mathrm{J}$ versus $1 / \Delta \mathrm{P}_{\mathrm{T}}$ will give slope equal to $R_{m}+R_{f}$ and intercept equal to $\Phi$. For violet dye a plot with slope equal to 9.4619*10-2 (Pa.hr / m) and an intercept equal to $3.537^{*} 10-3(\mathrm{hr} / \mathrm{m})$ has been obtained.

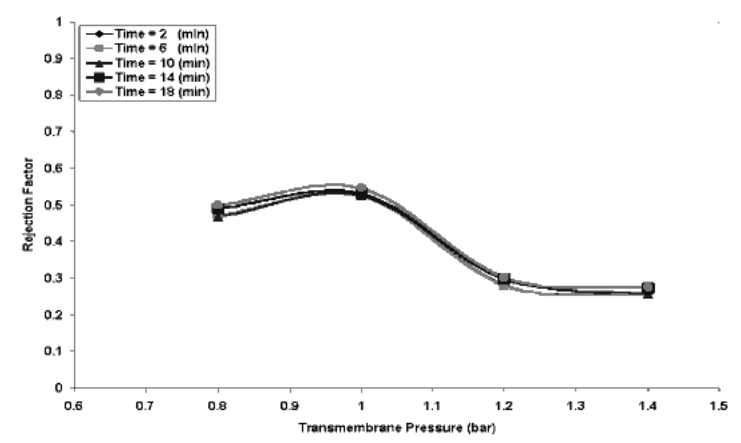

Fig.12. The effect of transmembrane pressure on the rejection factor of the red dye. $\mathrm{pH}=5 \mathrm{bar}, \mathrm{T}=30^{\circ} \mathrm{C}$, concentration $=50 \mathrm{ppm}$ and flow rate $=35.3 \mathrm{~L} / \mathrm{hr}$.

For the red dye, the slope is equal to $1.0457^{*} 10^{-2}(\mathrm{~Pa} . \mathrm{hr} / \mathrm{m})$ and an intercept is $9.4338^{*} 10^{3}(\mathrm{hr} / \mathrm{m})$. By calculating the flux using equation (4), the results show that theoretical flux values agree with experimental ones with difference of $2 \%$ to $21 \%$ in most cases as shown in Figures (13) and (14) for the violet and red dyes respectively. This can be explained in terms of tubular pinch effect.

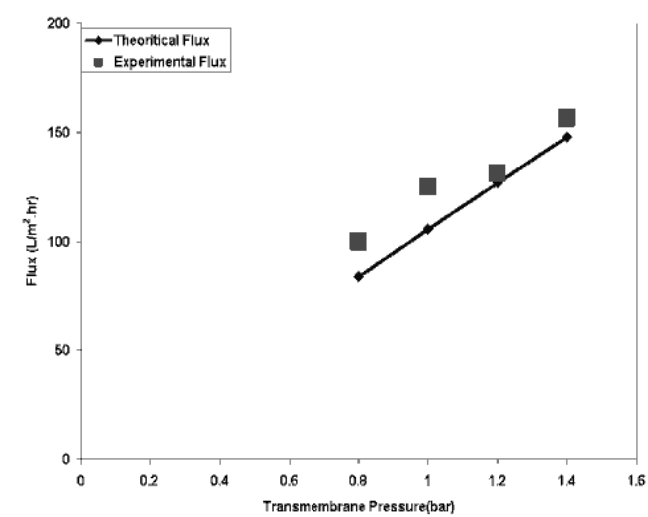

Fig. 13. The relation between theoretical and experimental fluxes for violet dye.
This phenomenon was first observed by Serge and Silberberg (1956) and explained as follow: as the particles were flowing through a tube, particles were migrating away from the tube wall and tube axis, reaching equilibrium at some eccentric radial position.

Another reason can be due to experimental and personal errors during performing the experiments including errors in taking the readings and weighing the dyes, etc.

\subsection{MiXTURE OF DYES}

After determining the best conditions where high percent of removal of violet and reactive red dyes was obtained, the flux and membrane performance were studied using mixture of dyes in different ratio. 10:1, 10:3, 10:5, 10:7, 10:9 and 10:10 ratios were used in this study.

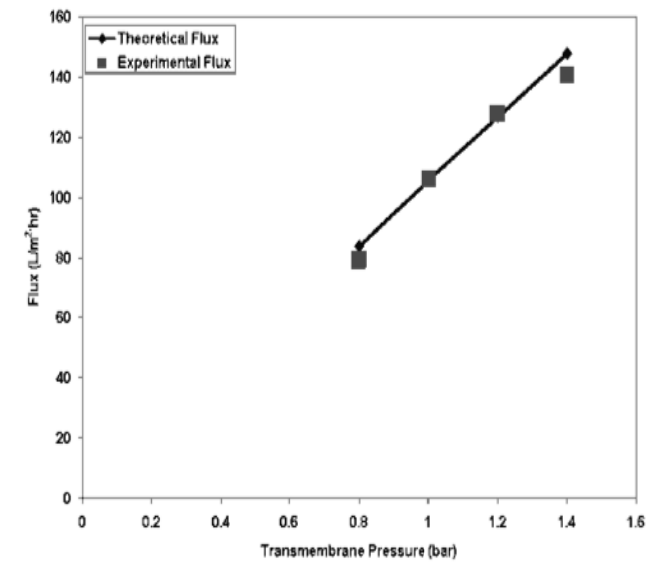

Fig. 14. The relation between theoretical and experimental fluxes for red dye.

From the results, it can be noticed that in the case of constant violet dye concentration and different red dye concentration that by increasing concentration of the reactive red dye, the flux was decreased. For the case in which red dye was in constant concentration and the violet dye in different concentration, as the violet dye concentration increases, a decline in flux was observed. Fig. (15) shows this behavior. By comparing the run of dyes mixture with concentration equal to $50 \mathrm{ppm}$ 
with respect to both dyes to that runs of single dye with concentration equal to $50 \mathrm{ppm}$ and $100 \mathrm{ppm}$ for violet and red dye, it was observed that the flux of the mixture solution is higher than that in the case of single dye solution for both dyes and both concentrations. Figures (16) and (17) show this situation.

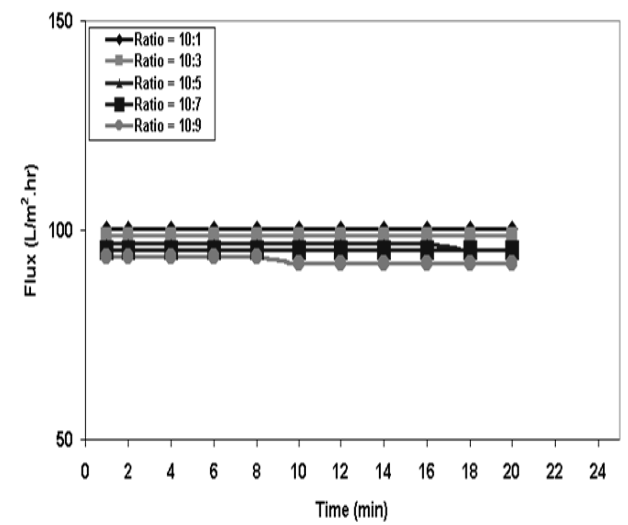

Fig. 15. The effect of ratio on flux as a function of time for the case of constant red dye concentration

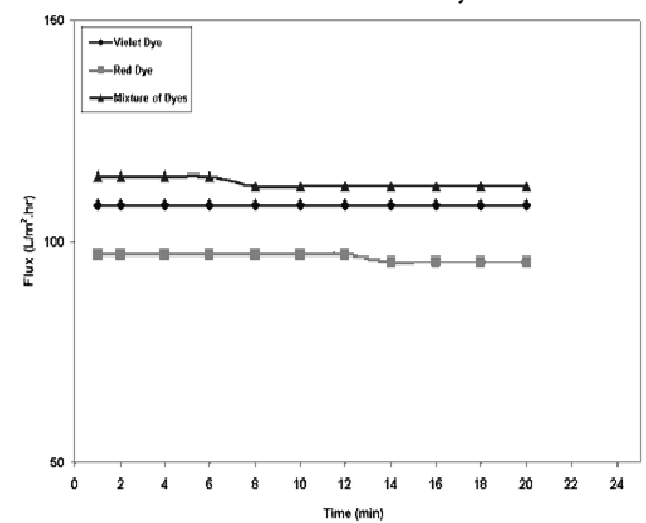

Fig. 16. The comparison of fluxes of mixture of dyes (concentration $=50 \mathrm{ppm}$ with respect of the two dyes) with that of individual dyes at concentration $=50 \mathrm{ppm}$.

With respect to rejection factor and on the case of constant violet concentration, by increasing the concentration of red dye, the rejection factor of red dye was increased and that of violet dye was decreased. The behavior can be explained by considering that violet dye molecule is larger than red dye molecule (since violet dye behavior in all experiments assures this assumption). In this case, if the membrane retains the larger solute, it may form a secondary-dynamic membrane on the primary membrane surface. Secondary membrane (if the larger solute is present in sufficient concentration) can be more retentive than the primary membrane and hindering the passage of the smaller molecules. This is in the case of high concentration of violet dye and low concentration of red dye. As the red dye increase in concentration, the rejection of the two dyes began to decrease.

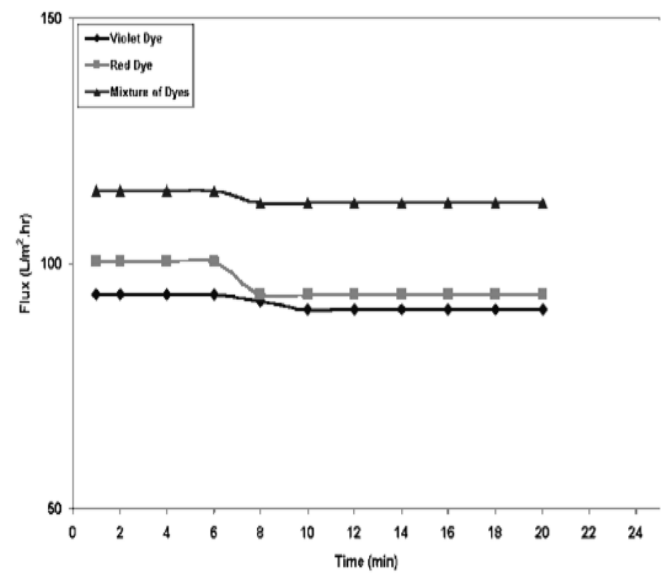

Fig.17. The comparison of fluxes of mixture of dyes (concentration $=50 \mathrm{ppm}$ with respect of the two dyes) with that of individual dyes at concentration $=100$ ppm.

Similar behavior was observed in the other cases in which the reactive red dye has constant concentration. A comparison was made between rejection factor values of the mixture solution $(50 \mathrm{ppm}$ violet and $50 \mathrm{ppm}$ reactive red) with that of the two dyes in single solution at $50 \mathrm{ppm}$ and $100 \mathrm{ppm}$, it was observed that the behavior of dyes in the mixture is close to the behavior of individual dye a concentration equal to $50 \mathrm{ppm}$ and differ from that at concentration equal to 100 ppm. This concludes that there are no interactions between the two dyes and they behave as if they were single in the solution. Figures (18) and (19) show this behavior.

\subsection{SyNTheTIC TEXTILE INDUSTRY EFFLUENT}

In this part of research, solutions having the same properties as the wastewater effluents 
from textile factory were prepared. For violet dye, a rapid decline in flux was obtained within 20 minutes. Similar behavior was observed for red dye. Figure 20 shows this decline for violet dye. Low percentage of dye removal was observed for violet dye (7\%). But for red dye, $85 \%$ of dye removal was achieved at the beginning and then decrease to $20 \%$. This may be because of the effect of the addition of materials such as wetting agent, anti-creasing agent, $\mathrm{Na}_{2} \mathrm{CO}_{3}$ and $\mathrm{Na}_{2} \mathrm{SO}_{4}$ on the dye. These materials may facilitate the passage of dye molecules through membrane pores.

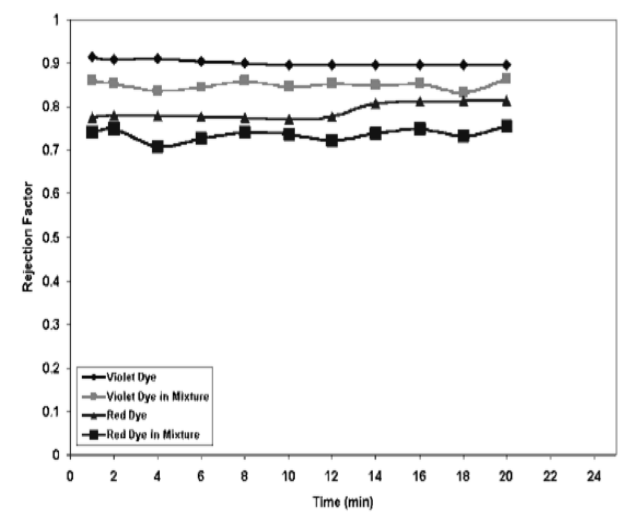

Fig. 18. The comparison of rejection factors for mixture of dyes (concentration $=50 \mathrm{ppm}$ with respect of the two dyes) with that of individual dyes at $=50 \mathrm{ppm}$.

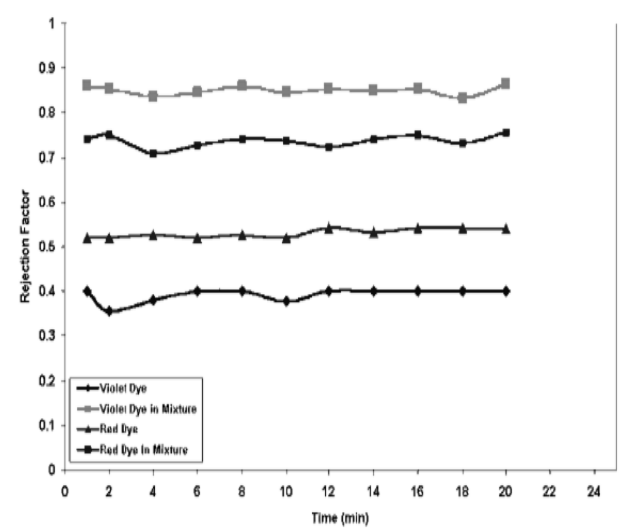

Fig.19. The comparison of rejection factors for mixture of dyes (concentration $=50 \mathrm{ppm}$ with respect of the two dyes) with that of individual dyes at concentration $=100 \mathrm{ppm}$.

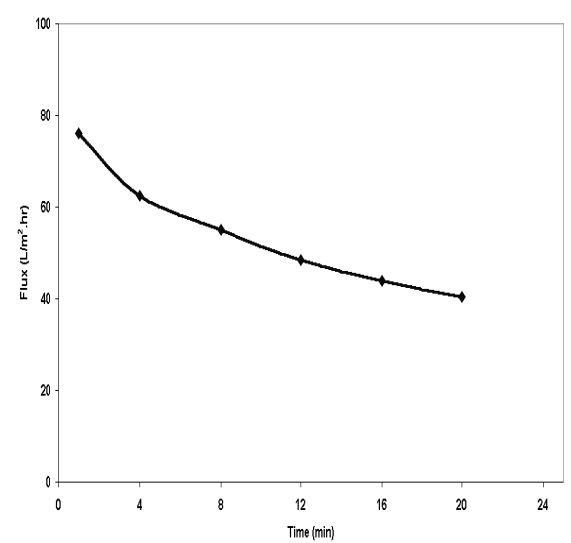

Fig.20. The effect of time on the flux of violet dye.

\section{CONCLUSIONS}

Removal percentage of about $91 \%$ for violet dye and about $87 \%$ for red dye removal was achieved and this may indicate the possibility of using hollow fiber ultrafiltration membrane made of polysulfone for the removal of reactive dyes from aqueous solutions.

Increasing flow rate from 8.5 to 35.3 (L/hr), $\mathrm{pH}$ from 3 to 11 and decreasing temperature from 50 to $25\left({ }^{\circ} \mathrm{C}\right)$ and feed concentration, all these factors lead to improvement membrane performance. This accentuates the effect of the operating parameters on the performance of the membrane. The behavior of dyes in the binary system is close to the behavior of dyes in the single system and this would indicate that interactions between the two dyes in the mixture solutions did not exist. So the two dyes can be treated as if they present as single in dye solution.

Resistance In Series model showed a good flux prediction in most experiments. Thus, it can be inferred that this model can be used to simulate Ultrafiltration processes under the experimental conditions studies.

\section{NOMENCLATURE}

$\mathrm{C}_{\mathrm{f}}: \quad \begin{aligned} & \text { Concentration of solute in the feed } \\ & \text { stream }(\mathrm{ppm}) .\end{aligned}$
$\mathrm{C}_{\mathrm{p}} \quad: \quad \begin{aligned} & \text { Concentration of solute in the } \\ & \text { permeate stream }(\mathrm{ppm}) .\end{aligned}$
$\mathrm{J}_{\mathrm{v}} \quad: \quad$ Permeate flux through the membrane


$\left(\mathrm{cm}^{3} / \mathrm{cm}^{2} \cdot s\right)$.

$\begin{array}{ccl}\mathrm{d}_{\mathrm{h}} & : & \text { Channel diameter }(\mathrm{cm}) . \\ \mathrm{J}_{\mathrm{w}} & : & \text { Pure water flux }(\mathrm{cm} 3 / \mathrm{cm} 2 . s) . \\ \mathrm{P}_{\mathrm{i}} & : & \text { Inlet membrane pressure (bar). } \\ \mathrm{P}_{\mathrm{o}} & : & \text { Outlet membrane pressure (bar). } \\ \mathrm{P}_{\mathrm{p}} & : & \text { Permeate backpressure (bar). } \\ \mathrm{R} & : & \text { Rejection coefficient. } \\ \mathrm{R}_{\mathrm{f}} & : & \text { Resistance due to fouling phenomenon } \\ & & \text { (Pa.hr/m). } \\ \mathrm{R}_{\mathrm{m}} & : & \text { Intrinsic membrane resistance } \\ \mathrm{R}_{\mathrm{P}} & : & \text { Resistance due to concentration } \\ & & \text { polarization phenomenon }(\mathrm{Pa} . \mathrm{hr} / \mathrm{m}) . \\ \Delta \mathrm{P}_{\mathrm{T}} & : & \text { The transmembrane pressure }(\mathrm{bar}) . \\ \Phi & : & \text { Proportional constant. }\end{array}$

\section{REFERENCES}

[1] Lin, S. H. and Chen, M. L., Treatment of Textile Wastewater by Chemical Methods for Reuse, Wat. Res., 31(4):868-876, 1997.

[2] O'Mahony, T., Guibal, E., and Tobin, J.M., Reactive dye biosorption by Rhizopus arrhizus biomass, Enzyme and Microbial Technology, 31: 456-463, 2002.

[3] Al-Degs, Y. S., Adsorption of Anionic Reactive Dyes on Activated Carbon from Aqueous Solution. Ph.D. Thesis, Queen's University, Balfast, UK, 2000.

[4] Majewska-Nowak, K., The effect of a polyelectrolyte on the efficiency of dye-surfactant solution treatment by ultrafiltration, Desalination, 221: 395-404, 2008.

[5] Susanto, H. and Ulbricht, M., Influence of Ultrafiltration Membrane Characteristics on Adsorptive Fouling with Dextrans. Membrane Science, 266 (1-2): 132-142, 2005.

[6] Harriott, P., McCabe, W. L. and Smith, J. C., Unit Operations of Chemical Engineering, McGraw-Hill, Inc, New York, $5^{\text {th }}$ edition, 1993.

[7] Geankoplis, C. J., Transport Processes and Unit Operations, Prentice-Hall International, Inc., U.S.A., $3^{\text {rd }}$ edition, 1993.

[8] [8] Yeh, H. M. and Wu, H. H., Membrane Ultrafiltration in Combined Hollow Fiber Module Systems. Membrane Science, 124:93-105, 1997.

[9] Cheryan, M., Ultrafiltration Handbook, Technomic Publishing Company, Inc., U.S.A., $1^{\text {st }}$ edition, 1986.

[10] Winnicki, T., Nowak, M. and Korbutowicz, K., Capillary Membranes for Separation of Dye Particles, Desalination, 105:91-103, 1996.
[11] Majewska, K., Winnicki, T. and Wisniewski, J., Ultrafiltration of Dyes by Polysulfone Membranes. In: Pawlowski, L., Physico-chemical Methods For water and Wastewater Treatment, Elsevier Scientific Publishing Company Amsterdam, $1^{\text {st }}$ edition, 1981.

[12] Caric', M. D., Milanovic', S. D., Krstic', D. M. and Tekic', M. N, Fouling of Inorganic Membranes by Adsorption of Whey Proteins. Membrane Science, 165:83- 88, 2000.

[13] Nakao, S. and Kimura, S., Analysis of Solutes Rejection in Ultrafiltration, Jap. J. Chem. Eng., 14(1): 33-37, 1981.

[14] Ahmad, A.L. and Puasa, S.W., Reactive dyes decolourization from an aqueous solution by combined coagulation/micellar-enhanced ultrafiltration process, Chemical Engineering Journal, 132: 257-265, 2007.

[15] Porter, M. C., Membrane Filtration. In: Schweitzer, P. E. and Philip, A., Handbook of Separation Techniques, McGraw-Hill Book Company, New York, $2^{\text {nd }}$ edition, 1988.

[16] Porter, M. C., Concentration Polarization with Membrane Ultrafiltration, Ind. Eng. Chem. Proc. Res. Devel., 11(3): 234-248, 1972.

[17] Grieves, R. B., Bhattacharyya, D., Schomp, W. G. and Bewley, J. L., Membrane Ultrafiltration of a Nonionic Surfactant, AIChE, 19(4): 766-774, 1973.

[18] Joseph, J. S., Ronald, F. and Shen, F., On the Prediction of Limiting Flux in Laminar Ultrafiltration of Macromolecular Solutions, Ind. Eng. Chem. Fundam., 16(4): 459- 465, 1977.

[19] Matsuyama, H., Shimomura, T. and Teramoto, M., Formation and Characteristics of Dynamic Membrane for Ultrafiltration of Protein in Binary Protein System. Membrane Science, 29: 107-115, 1994.

[20] Purkait, M.K., DasGupta, S. and De, S., Removal of Dye from Wastewater Using Micellar-Enhanced Ultrafiltration and Recovery of Surfactant. Separation and Purification Technology, 37: 81-92, 2004.

[21] Rudie, B., Condiff, R. and Kariniemi, P., Influence of Operating Parameters on Ultrafiltration Membrane: Dextran Rejection. International Congress on Membranes and Membrane Processes, 1990. 


\section{إزالة خليط من الأصباغ من المياه العادمة الصناعية باستخدام الترشيح الدقيق \\ عماد القدع' و نعمان حيمور'

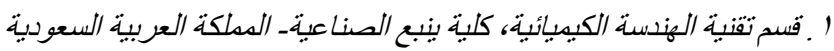

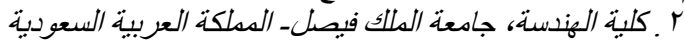

الملخص:

لقد تم في هذا البحث دراسة إمكانية استخدام الترشيح الدقيق في إزالة خليط من الأصباغ من المياه العادمة

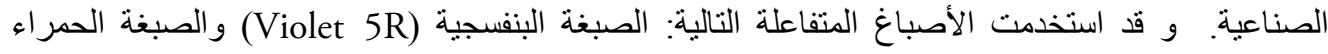
(Red 222.1). و قد قسمت التجارب إلى قسمين : قسم بعنى بدر اسة هذه الأصباغ على إنفر اد وتحديد الآثار التي تتتج عن تغيير ظروف التجربة مثل تغيير سرعة التدفق، درجة الحرارة، الضغط، التركيز، الرقم الهيدروجيني للمحلول و الزمن. القسم الآخر يبحث مقدرة الترشيح الدقيق في إز الة الأصباغ عند وجودها بشكل خليط وبنسب مختلفة. و قد وصلت عملية الفصل إلى ا9\% و و^\% بالنسبة للصبغتين البنفجية والحمر اء على التوالي. عند تدفق

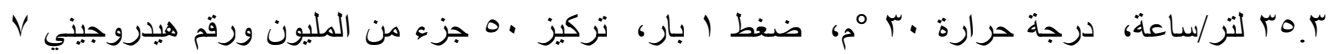
(متعادل) للصبغة البنفجية ورقم هيدروجيني 11 (قاعدي) للصبغة الحمر اء. وجد ان سرعة تدفق المحلول والرقم الهيدروجيني لهما أكبر الأثر في إزالة الصبغة البنفسجية من المحلول في حين كان الرقم الهيدروجيني صاحب الأثر الاكبر في عملية إزالة الصبغة الحمر اء. في القسم الثاني تبين أن وجود صبغتين في المحلول لا يؤثر على كفاءة الإزالة بسبب عدم وجود تداخل بين

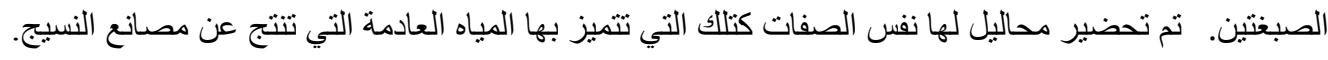

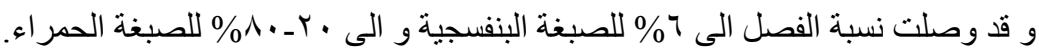
تم تطبيق النموذج الرياضي (Resistance In Series) لإيجاد القيم النظرية للتدفق والتي وجدت انها تطابق القيم

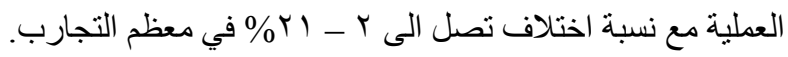

